\title{
Bilateral Anatomical Variation in the Formation of Trunks of the Brachial Plexus - A Case Report
}

\author{
E.F. Lasch ${ }^{1}$ M.B. Nazer ${ }^{1} \quad$ L.M. Bartholdy ${ }^{1}$ \\ ${ }^{1}$ Laboratório de Anatomia Humana, Departamento de Biologia e \\ Farmácia, Universidade Santa Cruz do Sul - UNISC, Santa Cruz do Sul, \\ Rio Grande do Sul, Brazil
}

J Morphol Sci 2018;35:9-13.

\begin{abstract}
Address for correspondence E. F. Lasch, Laboratório de Anatomia Humana, Departamento de Biologia e Farmácia, Universidade Santa Cruz do Sul - UNISC, Av Independência, 2293, CEP 96815-900, Santa Cruz do Sul, RS, Brazil (e-mail: evertonlasch@hotmail.com).
\end{abstract}

\begin{abstract}
Keywords

- brachial plexus

- trunks

This study presents a bilateral variation in the formation of trunks of brachial plexus in a male cadaver. The right brachial plexus was composed of six roots (C4-T1) and the left brachial plexus of five roots (C5-T1). Both formed four trunks thus changing the contributions of the anterior divisions of the cervical nerves involved in the formation of the cords and the five main somatic motor nerves for the upper limb. There are very few case reports in the scientific literature on this topic; thus making the present study very relevant.
\end{abstract}

\section{Introduction}

Most of the upper limb nerves arise from by the brachial plexus (BP), which has a complex anatomical structure that begins in the root of the neck and extends to the axilla (armpit region). The BP is formed by the anterior rami of the lower four cervical nerves ( $\mathrm{C} 5-\mathrm{C} 8$ ) and first thoracic nerve (T1), which form the roots of the brachial plexus. ${ }^{1-3}$ Generally, the roots of BP nerves pass through the space between the anterior and middle scalene muscles along with the subclavian artery and join with each other by anastomosis leading to the formation of the upper trunk ( $\mathrm{C} 5$ and $\mathrm{C6}$ ), medium trunk (C7), and lower trunk (C8 and T1), accompanying the axillary artery under cover of the pectoralis major muscle. These three trunks pass through the cervicoaxillary canal, posterior or anterior the clavicle or behind; each trunk splits into anterior and posterior divisions: the anterior divisions from the upper and middle trunks form the lateral cord, the anterior divisions from the lower trunk form the medial cord, and the three posterior divisions from the posterior cord. ${ }^{2-4}$ The supraclavicular branches (descending branches) of BP arise from the trunk or from cervical nerves, parallel to the trunk, and are as follows: dorsal scapular nerve, suprascapular nerve, long thoracic nerve, and subclavian nerve. The short infraclavicular branches, namely axillary nerve, subscapular nerves, thoracodorsal nerve, and medial and lateral pectoral nerve, arise from the cords and innervate the shoulder muscles. The long infraclavicular branches, which extend longitudinally to the upper limb, are: the radial nerve, the ulnar nerve, and the median nerve. ${ }^{4,5}$

Variations in the formation of the BP are common and are usually related to the contribution of anterior rami of $\mathrm{C} 4$ and $\mathrm{T} 2$ nerve roots. When the superior root of the plexus is $\mathrm{C} 4$ and the inferior root is $\mathrm{C} 8$, it is a prefixed Brachia Plexus. When the superior root is $\mathrm{C} 6$ and the inferior root is $\mathrm{T} 2$, it is a postfixed BP. Variations may also occur in the formation of trunks, divisions and cords, in the origin and/or combination of branches, and in the relationship with the axillary artery and scalene muscles. ${ }^{2,3,5}$

The BP is of great importance in medical and surgical procedures and in making a diagnosis of orthopedic injuries, such as neurovascular compression of the subclavian artery and BP injuries. ${ }^{6}$ Brachial plexus blocks, such as the interscalene and inter-sternocleidomastoid blocks, are commonly employed anesthesia techniques for proximal upper extremity surgery. ${ }^{7}$ The knowledge of the anatomical variations of the BP is very important to anatomists, radiologists, anesthesiologists, and surgeons, mainly for making accurate diagnosis of nerve injuries and providing the most effective and appropriate treatment for injuries in the axillary region and upper limb. Moreover, from a clinical point of view, in terms received

April 13, 2016

accepted

February 7, 2018
DOI https://doi.org/

10.1055/s-0038-1660485. ISSN 2177-0298.
Copyright $\odot 2018$ by Thieme Revinter Publicações Ltda, Rio de Janeiro, Brazil
License terms

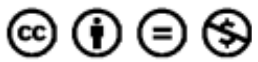


of anesthesia and surgical interventions, it is necessary to understand BP variations, morphometry, and possible anastomosis. $^{8,9}$

Due to their importance in surgical procedures involving the upper limb, variations of the brachial plexus have been addressed in the scientific literature in terms of their origin, formation, and distribution. Therefore, studies aimed at contributing to the morphological knowledge of BP and its variations are of paramount importance as a source of information and guidance for safe surgical procedures in brachial plexus injuries. Accordingly, the present study addresses a bilateral anatomical variation in the formation of trunks of the brachial plexus.

\section{Case Report}

During a routine dissection of a 60 year-old Caucasian male cadaver fixed in $10 \%$ formalin, in the Human Anatomy Laboratory of the University of Santa Cruz do Sul, RS, Brazil, we found a bilateral variation in the formation of the trunks of the brachial plexus; there were four trunks instead of the usual three.
The right brachial plexus/RBP ( - Fig. 1) was composed of six roots (C4-T1), which formed four trunks: first trunk (C4C5); second trunk (C6); third trunk (C7) and fourth trunk (C8-T1). The four trunks formed anterior divisions, and only the three superior trunks formed posterior divisions.

The posterior cord was formed by posterior divisions of the three superior trunks (C4-C7); the medial cord was formed by anterior divisions of the two lower trunks (C7T1); and the lateral cord was formed by anterior divisions of the first three trunks (C4-C7).

The median and ulnar nerves were formed by anterior divisions of the four trunks, where one branch originated from the lateral cord, called lateral root (C4-C7), and the other branch originated from the medial cord, called medial root (C8-T1). The axillary nerve was formed by the union of the two posterior divisions of the first (C4-C5) and second trunk (C6). The radial nerve originated from the posterior cord (C4-C7) and had no communication with the C8 and T1 roots; the musculocutaneous nerve was formed by the three anterior divisions of the three superior trunks (C4-C7).

The left brachial plexus/LBP (-Fig. 2) was composed of five roots (C5-T1), which formed four trunks: first trunk (C5);

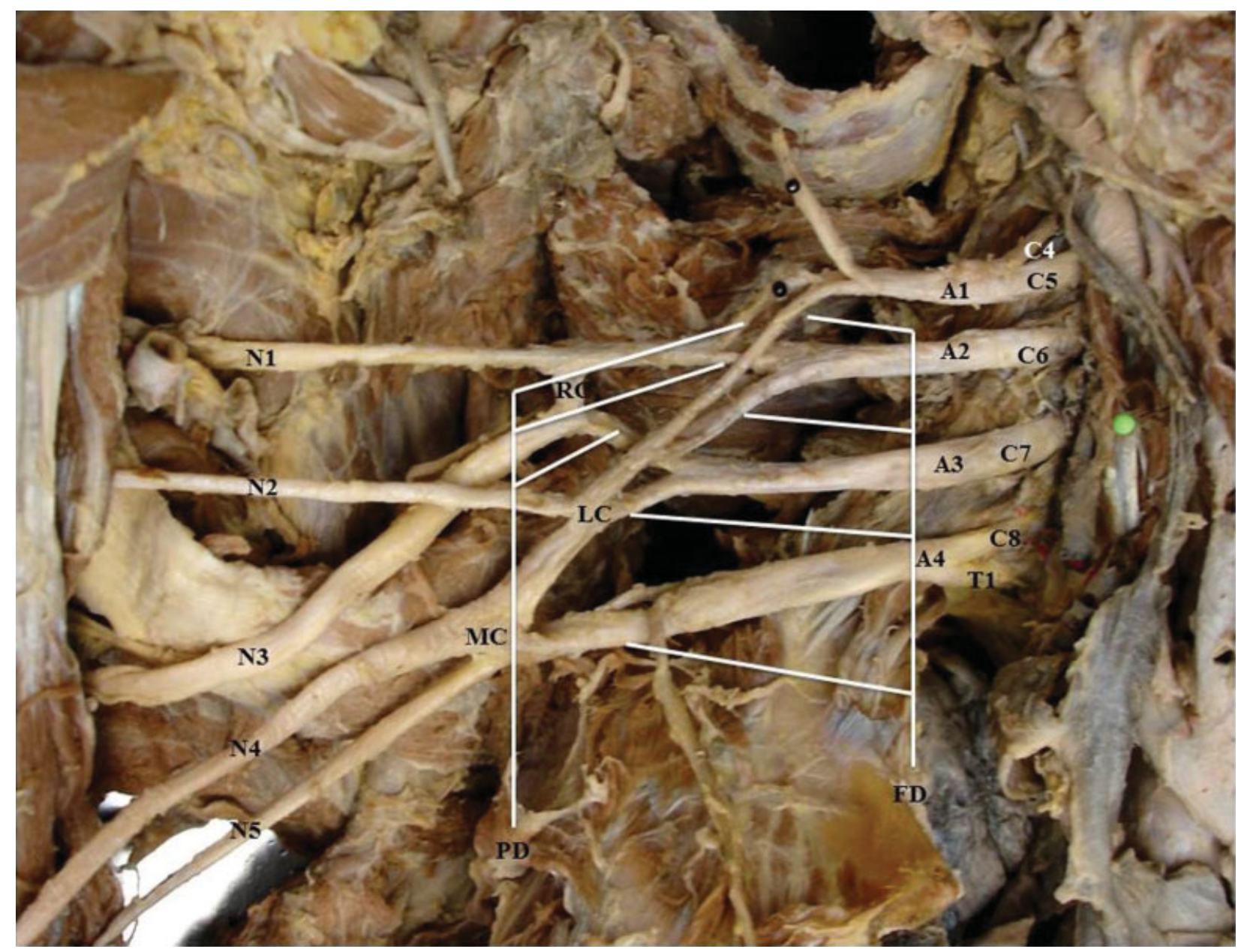

Fig. 1 Right brachial plexus: C4 (Roots of the C4), C5 (Roots of the C5), C6 (Roots of the C6), C7 (Roots of the C7), C8 (Roots of the C8), T1 (Roots of the T1). A1 (First trunk), A2 (Second trunk), A3 (Third trunk) and A4 (Fourth trunk). RC (Rear Cord), MC (Medial cord) and LC (Lateral Cord). N1 (Axillary Nerve), N2 (Musculocutaneous Nerve), N3 (Radial Nerve), N4 (Median Nerve) and N5 (Ulnar Nerve). FD (Former Divisions) and PD (Posterior Divisions). 


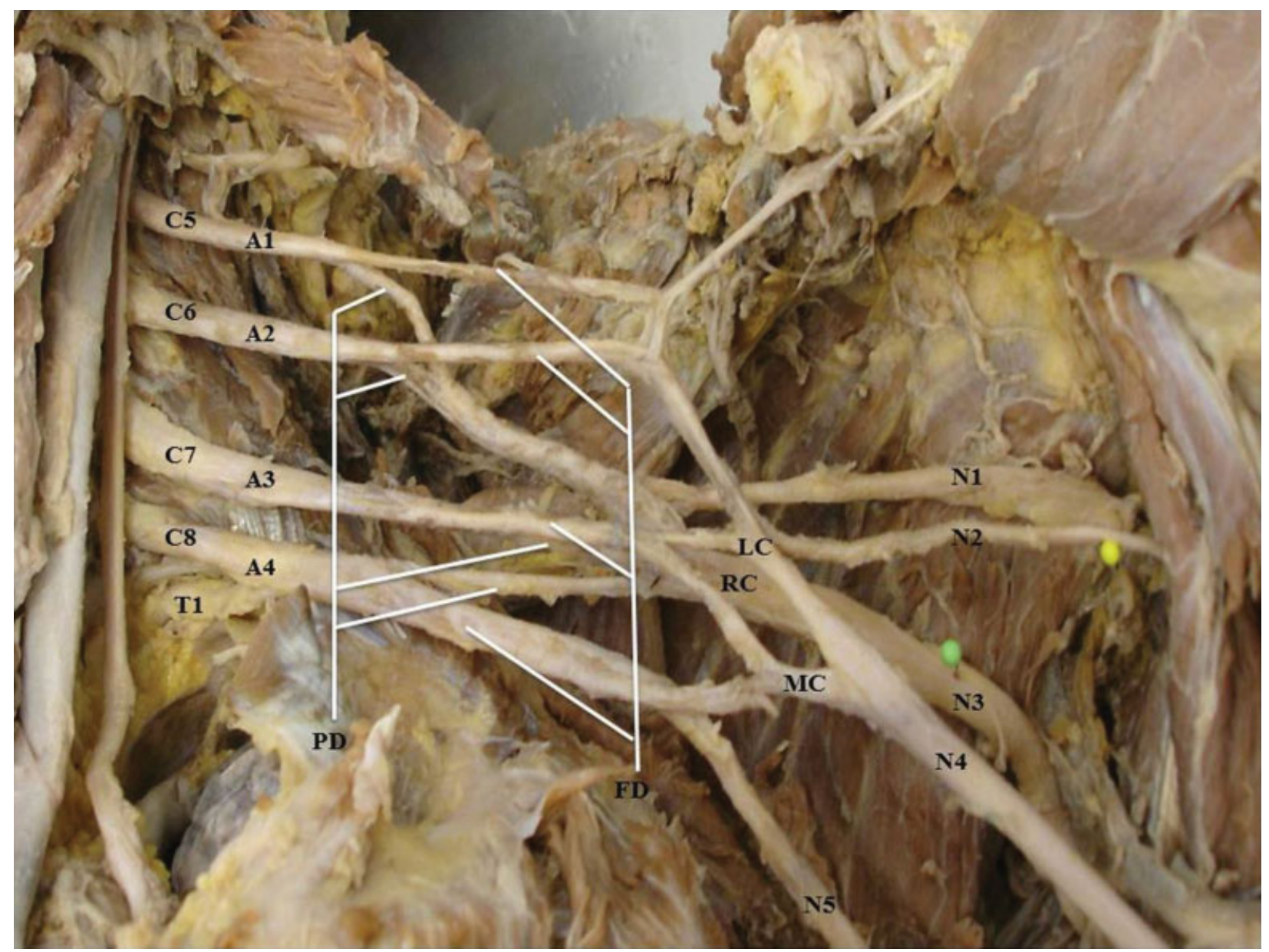

Fig. 2 Left brachial plexus: C5 (Roots of the C5), C6 (Roots of the C6), C7 (Roots of the C7), C8 (Roots of the C8), T1 (Roots of the T1), A1 (First trunk), A2 (Second trunk), A3 (Third trunk) and A4 (Fourth trunk). RC (Rear Cord), MC (Medial cord) and LC (Lateral Cord). N1 (Axillary Nerve), N2 (Musculocutaneous Nerve), N3 (Radial Nerve), N4 (Median Nerve) and N5 (Ulnar Nerve). FD (Former Divisions) and PD (Posterior Divisions).

second trunk (C6); third trunk (C7), and fourth trunk (C8 and T1). All four trunks formed anterior and posterior divisions.

The posterior cord was formed by posterior divisions of the four trunks (C5-T1); the medial cord was formed by anterior divisions of the third (C7) and fourth trunk (C8 and $\mathrm{T} 1$ ); the lateral cord was formed by anterior divisions of the first three trunks (C4-C7).

The median nerve was formed by anterior divisions of the four trunks (C5-T1), where one branch originated from the lateral cord, called lateral root (C5-C7), and the other branch was originated from the medial cord, called medial root (C7$\mathrm{T} 1$ ). The ulnar nerve was formed by anterior divisions of the third (C7) and fourth trunk (C8 and T1). The axillary nerve was formed by posterior divisions of the first (C5) and second trunk (C6). The radial nerve was formed by the posterior divisions of the four trunks (C5-T1); the musculocutaneous nerve was formed by anterior divisions of the two superior trunks (C5 and C6).

The Tables below show a summary of the contributions of the roots to the formation of the trunks of the brachial plexus: - Table 1, typical pattern described in the literature according to Standring ${ }^{3}$; - Table 2, right brachial plexus; and - Table 3, left brachial plexus.

\section{Discussion}

The present study demonstrates a bilateral variation in the formation of the BP trunks, in which the RBP was composed of six roots (C4-T1) and the LBP of five roots (C5-T1). The nerve fibers that contribute to the formation of the upper limb nerves showed variations due to the presence of four trunks. There are very few reports in the scientific literature addressing cases of BP with four trunks. Investigating 60 BPs which belonged to 30 cadavers, Chaudhary et $\mathrm{al}^{10}$ found four trunked brachial plexuses on the left side in three cases. Of the three cases, one BP (prefixed and postfixed) was composed of roots $\mathrm{C} 4 \mathrm{-T} 2$ which formed four trunks: first trunk (C4-C6), second trunk (C7), third trunk (C8), and fourth trunk (T1 and T2). In the other two cases, the BPs (postfixed) were composed of C5-T2 roots, which formed four trunks: first trunk (C5 and C6), second trunk (C7), third trunk (C8), and fourth trunk (T1 and T2). Although the same variation of four trunked plexus was found in the present study, these authors found different variations in terms of the fibers from which they originate and trunk endings.

During routine dissection of a female cadaver, Singla et al. ${ }^{11}$ found two trunks instead of the usual three in the 
Table 1 typical pattern described in the literature according to Standring ${ }^{3}$

\begin{tabular}{|l|l|l|}
\hline Cords & Nerve & Roots \\
\hline \multirow{3}{*}{ Lateral } & Musculocutaneous & $\mathrm{C} 5, \mathrm{C} 6, \mathrm{C} 7$ \\
\cline { 2 - 3 } & $\begin{array}{l}\text { Roots lateral of the } \\
\text { nerve median }\end{array}$ & $\mathrm{CC} 5), \mathrm{C} 6, \mathrm{C} 7$ \\
\hline \multirow{2}{*}{ Medial } & Ulnar & $\mathrm{C} 7, \mathrm{C} 8, \mathrm{~T} 1$ \\
\cline { 2 - 3 } & $\begin{array}{l}\text { Roots medial of the } \\
\text { nerve median }\end{array}$ & $\mathrm{C} 8, \mathrm{~T} 1$ \\
\hline Posterior & Axillary & $\mathrm{C} 5, \mathrm{C} 6$ \\
\cline { 2 - 3 } & Radial & $\mathrm{C} 5, \mathrm{C} 6, \mathrm{C} 7, \mathrm{C} 8,(\mathrm{~T} 1)$ \\
\hline
\end{tabular}

Table 2 Right brachial plexus

\begin{tabular}{|l|l|l|l|}
\hline Cords & Nerve & Roots & Note \\
\hline Lateral & Musculocutaneous & $\begin{array}{l}\text { C4, C5, } \\
\text { C6, C7 }\end{array}$ & + C4 \\
\cline { 2 - 4 } & $\begin{array}{l}\text { Roots lateral of the } \\
\text { nerve median }\end{array}$ & $\begin{array}{l}\text { C4, C5, } \\
\text { C6, C7 }\end{array}$ & + C4 \\
\cline { 2 - 4 } & $\begin{array}{l}\text { Roots lateral of } \\
\text { the nerve ulnar }\end{array}$ & $\begin{array}{l}\text { C4, C5, } \\
\text { C6, C7 }\end{array}$ & + C4 \\
\hline Medial & $\begin{array}{l}\text { Roots medial of } \\
\text { the nerve ulnar }\end{array}$ & C8, T1 & - C7 \\
\cline { 2 - 4 } & $\begin{array}{l}\text { Roots medial of the } \\
\text { nerve median }\end{array}$ & C8, T1 & \\
\hline Posterior & Axillary & $\begin{array}{l}\text { C4, C5, } \\
\text { C6 }\end{array}$ & + C4 \\
\cline { 2 - 4 } & Radial & $\begin{array}{l}\text { C4, C5, } \\
\text { C6, C7 }\end{array}$ & + C4 / - \\
& & C 11 \\
\hline
\end{tabular}

$(+)$ : inclusion in the formation; (-): absence in the formation.

RBP: upper trunk (C5 and C6) and the lower trunk (C7, C8, and $\mathrm{T} 1$ ) with an absence of the middle trunk. Yildiz et $\mathrm{al}^{12}$ found the same variation in a male cadaver in the LBP.

In another study, Shetty et $\mathrm{al}^{13}$ found unilateral variations in the formation of the trunks in five (11.3\%) of 44 cadavers

Table 3 Left brachial plexus

\begin{tabular}{|l|l|l|l|}
\hline Cords & Nerve & Roots & Note \\
\hline \multirow{3}{*}{ Lateral } & Musculocutaneous & $\mathrm{C} 5, \mathrm{C} 6$ & $-\mathrm{C} 7$ \\
\cline { 2 - 4 } & $\begin{array}{l}\text { Roots lateral of the } \\
\text { nerve median }\end{array}$ & $\mathrm{C} 5, \mathrm{C} 6, \mathrm{C} 7$ & \\
\hline \multirow{3}{*}{ Medial } & Ulnar & $\mathrm{C7}, \mathrm{C} 8, \mathrm{~T} 1$ & $-\mathrm{C} 7$ \\
\cline { 2 - 4 } & $\begin{array}{l}\text { Roots medial of the } \\
\text { nerve median }\end{array}$ & $\mathrm{C} 7, \mathrm{C} 8, \mathrm{~T} 1$ & $+\mathrm{C} 7$ \\
\hline Posterior & Axillary & $\mathrm{C} 5, \mathrm{C} 6$ & \\
\cline { 2 - 4 } & Radial & $\begin{array}{l}\mathrm{C} 5, \mathrm{C} 6, \\
\mathrm{C7}, \mathrm{C} 8, \mathrm{~T} 1\end{array}$ & \\
\hline
\end{tabular}

$(+)$ : inclusion in the formation; (-): absence in the formation. investigated. In one cadaver (2.27\%), the middle trunk was formed by the union of $\mathrm{C} 7$ and $\mathrm{C} 8$ roots, and the lower trunk was formed by the T1 root. In another cadaver (2.27\%), the upper and middle trunks were fused with each other. In the other three cadavers (6.81\%), the C5 root pierced the anterior scalene muscle before joining $\mathrm{C} 6$ to form the upper trunk.

The prevalence of anatomical variants of the brachial plexus is addressed in different specimens in the literature. One of the first common variants described is the prefixed or postfixed types of BP. ${ }^{14}$ In the present study, a prefixed RBP was found, in which the $\mathrm{C} 4$ roots contribute to its formation, but the $\mathrm{T} 1$ root is not smaller or absent and is similar in caliber to the other roots. Ongoïba et $\mathrm{al}^{15}$ and Bowden ${ }^{16}$ argue that the prevalence rates for the prefixed type range from 12 to $30 \%$, and that the postfixed type occurs in $0 \%$ to $11 \%$ of the cases. In a study conducted in Brazil, it was found a prevalence of the prefixed type in $20 \%$ to $24 \%$ of cases, and the postfixed type in $0 \%$ to $6 \%$ of the cases. ${ }^{17}$

Fazan et al., ${ }^{1}$ evaluated 54 BPs in 27 cadavers and found normally formed BPs in 39 cadavers (72\%) and prefixed BPs in 13 cadavers (24\%); two males and eleven females (54\% RBPs and 46\% LBPs). Only three BPs were postfixed and they were found in male cadavers, two in the right antimere and one in the left antimere. According to the authors, intercordal neural communications between the lateral and medial cords are relatively common, especially between the lateral cord and the ulnar nerve or between the median nerve and the musculocutaneous nerve. They found communications between the lateral cord and the ulnar nerve in $30 \%$ of cases. The same variation was found by Harris ${ }^{14}$ in 26 (86.66\%) of the 30 upper limbs studied by this author.

Investigating 32 upper limbs in 16 formalin-fixed Brazilian cadavers of both sexes, Olave et $\mathrm{al}^{18}$ found a communicating branch between the musculocutaneous nerve and the median nerve in ten cases (31.3\%), nine males, four in the right antimere and six in the left antimere, and two with bilateral variation. Chiarapattanakom et al $^{19}$ found the same communication branch in $21.8 \%$ of $57.3 \%$ cases investigated. In 75 (90.5\%) of the cases studied by Tountas and Bergman, ${ }^{20}$ the musculocutaneous nerve originated from the BP, $2 \%$ originated from the median nerve, and $1.4 \%$ from the posterior cord. In the present study, it was found a communicating branch between the musculocutaneous and median nerves in the BP in both antimeres. In the RBP, the radial nerve was formed by the posterior cord (C4-C7) showing no communication with the $\mathrm{C} 8$ and $\mathrm{T} 1$ roots, and the axillary nerve was formed from the fusion of the two posterior divisions of the first (C4-C5) and second trunk (C6).

According to Albertoni et al., ${ }^{17}$ the prevalence rates of anatomical variants of the BP varies depending on the population studied and can be up to $48 \%$. In some individuals, the trunk divisions or the cord formations may be absent in different parts of the BP; However, the makeup of the terminal branches is invariable. Moreover, the lateral or medial cords may receive fibers from anterior divisions directly inferior or superior to the usual levels respectively, resulting in the fusion of different calibers the terminal branches. ${ }^{1,2}$ argue that 
variations in the BP are not influenced by gender or race and are more common in a certain antimere.

Gonzáles et $\mathrm{al}^{21}$ stated that severe BP injuries can cause shoulder paralysis due to disrupted innervation of the muscles. An epidemiological study on traumatic BP injuries in adults performed by Flores ${ }^{22}$ showed that the BP is very susceptible to injuries due to its anatomical position and relationship with other anatomical structures; therefore knowledge of anatomy is essential for treatment and injury prevention.

According to Olave et $\mathrm{al}^{18}{ }^{18}$ there may be nerve fibers that run for some distance in another nerve, to reach their innervation territory and return to the nerve they belong to be distributed, which are sometimes denominated anastomotic communications and allow the understanding of the variations in the innervation territories of nearby nerves. Moreover, the presence of anatomical variations of the peripheral nervous system is often used to explain unexpected clinical signs and symptoms. Therefore, the knowledge of the distribution, route, and patterns of the rami of nerves, cords, trunks, and roots that make up the BP are fundamental for clinical investigations involving peripheral nerve injuries.

Considering that every individual may have some type of anatomical variation, the present study aims to deepen the knowledge of anatomical variations of the BP, which can be an important source of information to help healthcare professionals to acknowledge and interpret BP variations make accurate diagnosis, improve surgical safety, and provide effective treatment facilitating recovery.

\section{References}

1 Fazan VPS, Amadeu AS, Caleffi AL, Rodrigues Filho OA. Brachial plexus variations in its formation and main branches. Acta Cir Bras 2003;18(Suppl 5):14-18 Doi: 10.1590/S0102-86502003001200006

2 Moore KL, Dalley AF, Agur AMR. Anatomia orientada para a clínica. 6. ed. Rio de Janeiro: Guanabara Koogan; 2014:716-723

3 Standring S, Ed. Gray Anatomia: a base anatômica da prática clínica. 40. ed. Rio de Janeiro: Elsevier; 2010:818-822

4 Costabeber I, Almeida GM, Becker M, Silveira AF, Martini DT. Fascículos do plexo braquial: um estudo morfológico. Rev Bras Anestesiol 2010;60(06):614-619 Doi: 10.1016/S0034-7094(10) 70076-3

5 Aumüller G, Aust G, Doll A, et al. Anatomia. Rio de Janeiro: Guanabara Koogan; 2009:454
6 Evans RC. Exame físico ortopédico ilustrado. 2. ed. Barueri: Manole; 2003:1035

7 Dewees JL, Schultz CT, Wilkerson FK, Kelly JA, Biegner AR, Pellegrini JE. Comparison of two approaches to brachial plexus anesthesia for proximal upper extremity surgery: interscalene and intersternocleidomastoid. AANA J 2006;74(03):201-206

8 Oliveira IM, Silva PL, Corrêa KS. Estudo morfométrico da raiz lateral do nervo mediano. Arq Ciênc Saúde UNIPAR 2008;12(02): 105-108

9 Olave E, Gabrielli C, Braga MTT, Del Sol M. Aspectos biométricos de los ramos motores del nervio musculocutáneo para el músculo braquial. Rev Chil Anat 2002;20(02):231-236

10 Chaudhary P, Singla R, Kalsey G, Arora K. A four trunked brachial plexus and a post fixed brachial plexus: a conjunction or a coincidence? Report of three cases. Clin Anat 2012;25(05): 593-600

11 Singla RK, Sharma RK, Shree B. A two trunked brachial plexus: a case report. J Clin Diagn Res 2013;7(04):704-705

12 Yildiz S, Cömert A, Ozan H. A case of connected superior and middle trunks of the brachial plexus or with abnormal upper trunk. Rom J Morphol Embryol 2011;52(3, Suppl):11571159

13 Shetty SD, Nayak BS, Madahv V, Braganza CS, Somayaji SN. A study on the variations in the formation of the trunks of brachial plexus. Int J Morphol 2011;29(02):555-558 Doi: 10.4067/S071795022011000200042

14 Harris W. The true form of the brachial plexus, and its motor distribution. J Anat Physiol 1904;38(Pt 4):399-422, 5

15 Ongoïba N, Destrieux C, Koumare AK. [Anatomical variations of the brachial plexus]. Morphologie 2002;86(273):31-34

16 Bowden REM. The applied anatomy of the cervical spine and brachial plexus. Proc R Soc Med 1966;59(11 Part 1):1141-1146

17 Albertoni WM, Galbiatti JA, Canedo AC, Merlotti M. Estudo anatômico do plexo braquial na criança até os seis meses de idade. Rev Bras Ortop 1994;29:163-169

18 Olave E, Gabrielli C, Braga MTT, Del Sol M, Souza A. Ramo comunicante entre los nervios musculocutáneo y mediano en el hombre. Rev Chil Anat 2000;18(02):301-304

19 Chiarapattanakom P, Leechavengvongs S, Witoonchart K, Uerpairojkit C, Thuvasethakul P. Anatomy and internal topography of the musculocutaneous nerve: the nerves to the biceps and brachialis muscle. J Hand Surg Am 1998;23(02):250-255 Doi: 10.1016/ S0363-5023(98)80122-6

20 Tountas CHP, Bergman RA. Anatomic variations of the upper extremity. New York: Churchill Livingstone; 1993:196-210

21 Gonzáles RJM, Ramos HD, Santana PL, Gonzáles LFP. Transferência del trapecio en la parálisis del plexo braquial. Rev Cuba Ortop Traumatol 2007;21(01):1-6

22 Flores LP. Estudo epidemiológico das lesões traumáticas de plexo braquial em adultos. Arq Neuropsiquiatr 2006;64(01):88-94 Doi: $10.1590 /$ S0004-282 × 2006000100018 